\title{
OPHN1 Gene
}

National Cancer Institute

\section{Source}

National Cancer Institute. OPHN1 Gene. NCI Thesaurus. Code C127845.

This gene plays a role in the mediation of GT P hydrolysis of Rho subfamily members. 